\title{
Integrated model formation for the digital university development
}

\author{
N.V. Gorbunova ${ }^{1 *}$, R.R. Timirgaleeva ${ }^{2}$, and A.A. Khrulyova ${ }^{3}$ \\ ${ }^{1}$ V.I. Vernadsky Crimean Federal University, Simferopol, Russia \\ ${ }^{2}$ V.I. Vernadsky Crimean Federal University, Simferopol, Russia \\ ${ }^{3}$ V.I. Vernadsky Crimean Federal University, Simferopol, Russia
}

\begin{abstract}
In this article, based on the analysis of modern trends in the digital transformation of the education system, as well as taking into account the need to increase the efficiency of all processes implemented in the higher education system, the necessity of forming a digital model of the university is substantiated. The model implementation is aimed at constantly improving the higher education quality and the university competitiveness. The objective prerequisites for the formation of the complex model based on the socio-economic role of higher education are revealed. It has been proven that the accelerated development of digital technologies stimulates the creation and implementation of innovative education forms that can flexibly respond to changes in the external environment. The necessity of applying the model of lifelong education at the present stage is substantiated, the implementation of which will make it possible to form the competencies required by the labor market timely. An important condition for the digital competencies formation and development is the transition of the university to a digital development model, as well as the establishment of business ties with potential customers of educational services and employers. The implementation of the proposed model will make all business processes transparent, eliminate unproductive processes, which will lead to an increase in the efficiency and quality of educational services.
\end{abstract}

\section{A problem statement}

For the transition to a qualitatively new stage in the Russian Federation development, based on innovation and science, within which the intangible sphere turns into the most important factor in the economy competitiveness, knowledge is assigned a special role as a direct productive force and the main productive resource, which are the fundamental basis of the digital economy. Digitalization fills all spheres of society and human life. Digitalization is inextricably linked with personnel professional training, which is implemented in the format of hackathons, digital breakthroughs. The digitalization of higher education, the creation of digital universities are due to the need to find answers to the challenges of our

\footnotetext{
*Corresponding author: prof-ped.gpa@mail.ru
} 
time. In recent years, it is digitalization that has been an essential component of the economic, political, socio-cultural development of society.

An increasing role is played by innovative ideas, supported by deep analysis and intellectually intensive developments. This leads to the need for significant changes in the education system. Digital transformation of all spheres, including the education system, is a priority for ensuring the competitiveness of the country, region, individual industry and business entity. Digital transformation is inevitable, since the processes taking place in the world are associated not only with the objective appearance and development of new information technologies and systems, but also with the emergence of new business models for their application. A key condition for the education digital transformation is the formation of demand for digital technologies and their consumption by the education system, citizens, businesses, the state by eliminating legislative, institutional, fiscal, tax, currency and monetary barriers that impede the development of the digital economy in general and the education digital transformation in particular.

The ability of digital technologies to influence the productivity and efficiency of all processes implemented in the education system convincingly proves the feasibility of pursuing a state policy of digital transformation, including on the basis of public-private partnerships. The creation of a virtual educational environment for educators and students is already becoming commonplace. Methodological and informational materials, innovative developments and other materials are placed on the sites of information educational networks. These resources provide an opportunity to get online education, as well as improve your professional level. The use of information educational networks as a platform for the placement of various educational disciplines, the creation of a unified information educational environment is an important component of the digital transformation of education and an important trend in the education development in the 21 st century, the socalled open education.

Modernization of education through the introduction of digital technologies makes it possible to create a qualitatively new system for the implementation of human capital and the acquisition of digital competencies by citizens in accordance with changes in the economy, technology, and labor markets.

Today, there is an active transformation of the information society into a knowledge society, when ICTs begin to cover an increasing number of users, actively increasing the resource base. Modern society lives in a saturated information space, which requires education to solve certain problems, namely, not only to live an individual in this environment, but also to create conditions for his continuous education. In this regard, educational activity in the context of society globalization is undergoing continuous cardinal changes associated with informatization, the development of information and communication technologies (ICT), an increase in the rate of growth acceleration of the knowledge economy, deep and fast dynamics of changes, competencies and professional requirements in demand in the labor market.

\subsection{The objective of the work}

The innovative development of society and the humanitarian sphere of human activity is an important factor in socio-economic growth. In the context of a knowledge-based economy, higher education should become the basis for the economy of Russia and its regions for the formation of a technologically advanced society. The interest shown by researchers in the study of the role and place in the development of the national economy of different countries has increased significantly in recent years. This circumstance is determined by the general vector of development - the influence of the technological revolution and the knowledge economy on the formation and transformation of knowledge into innovation. 
Modeling involves the creation of the original object image, reflecting the properties and characteristics of the original, providing clarity, ease of operation. Thus, the model does not reflect the original object itself, but is formed based on the set goal, reflecting the specific properties of the object. The use of models allows making decisions, when justifying which all factors and alternatives arising in the conditions of real activity are taken into account. That is why the model is the most effective way to optimize management decisions.

As the analysis of a number of literary sources has shown, the issues of education system digital transformation have become the object of a number of researches aimed at studying various aspects of digitalization. The authors of a number of publications deeply analyze the essence of the term "digitalization", noting its role in the historical development of society. The study showed that digitalization can be viewed from different perspectives. On the one hand, this is not just an information transfer into "digital", but "a new paradigm of thought, communication, interaction with each other". On the other hand, this is a new stage in the society development, which leads to a life quality increase of the population and is a means of developing business processes and comprehensively solving problems of an infrastructural, managerial, behavioral and cultural nature.

The concept content of "the higher education digitalization" is much broader than the introduction of modern ICT technologies. The term "modern digital university" is becoming more and more familiar, which is completely new in structure, content of education, administrative approach, development of human capital, scientific potential, quality management system.

Scientists propose different models of digital universities, determine the criteria for readiness for digital transformation and indicators of their measurement, analyze the best practices for creating a digital university campus, study global trends in digital transformation and their impact on the creation of digital universities.

At the same time, many scientists note in their studies the presence of economic efficiency, as well as social and individual benefits of investments in higher education [1, 2]. Researchers note the possibility of short-term gains from investment in higher education in the form of increased employment and the benefits obtained from this in the long term, which are manifested through the individuals' growth of professionalism and competence, which, in turn, is reflected in their income. In turn, the growth of population incomes generates an increase in tax revenues, savings and investments, which contributes to an increase in the welfare of the whole society. In addition, higher education can significantly improve the social environment of society, increase the competitiveness of the country's economy.

Higher education built on a digital model is the important mechanism for the development of individual socio-economic progress and the important driving force for the economic mobility of each student, regardless of what kind of education he receives primary higher basic, second higher, retraining, advanced training, etc. It is now widely recognized, and scientists have proven it in their research, that a well-educated workforce is vital to a country's future economic growth. The analysis of a number of literary sources suggests that only highly qualified specialists can meet the needs of business and the social sector in the context of globalization.

Theoretical aspects and practical issues of economic development and innovation activity are considered in studies [3-5], the problems of higher education economic and innovative development are presented in researches [6-13], innovative development of society is disclosed in a number of studies $[14,15]$, the authors of which prove the close relationship between the country's competitiveness and innovation potential, emphasizing the need to support the country's higher education at the global level. 
At the same time, the issues of the integrated model forming for the digital university development, the implementation of which is aimed at constantly improving the quality of higher education, increasing the competitiveness of the university through the use of modern digital technologies, remain open, which requires additional researches.

\section{Results of the research}

As you know, higher education is not only an important sector of the national economic complex of the country, but also a social socio-economic process, including social and economic components, contributes to the innovative development of society and has a direct impact on its socio-economic growth. In this regard, it is necessary to note the complex socio-economic role of higher education in the process of expanded reproduction, including the reproduction of production relations between people in this area, which are characteristic of their specific patterns.

Attention should be paid to the Decree of the President of the Russian Federation of May 7, 2018 No. 204 "On national goals and strategic objectives of the development of the Russian Federation for the period up to 2024", aimed at solving problems to ensure the accelerated introduction of digital technologies into the economy and social sphere, and also the program "Digital Economy of the Russian Federation", on the basis of which the national program "Digital Economy of the Russian Federation" was formed. These programs cannot be successfully implemented without digital skills, which must be shaped by the education system. In this regard, the objective prerequisites for the decisive integrated socio-economic role of higher education in modern society are:

- the formation of the higher education system as an independent and specific industry;

- development of the scientific and technological revolution, that led to: a significant expansion of the scale of education; a significant expansion of costs for it, as well as an increase in the influence of education on the development of economic mechanisms of public administration, the rate of socio-economic growth, the efficiency of all types of production (individual, collective, public), differentiation of wages, etc.; the penetration of the principles, mechanisms and methods of a market economy into the sphere of higher education, the rapid commercialization of activities in the educational and scientific fields, the emergence of the phenomenon of academic entrepreneurship; highlighting such important human qualities as education, qualifications, economic thinking, responsibility, digital literacy and digital culture, communication skills, etc.;

- focus on creating a knowledge society with an innovation-oriented type of economy, which cannot be realized without highly educated human capital, intellectual capital, new knowledge and innovative technologies.

For modern universities, the challenges of our time have been actualized:

- search for optimal models of digitalization;

- ensuring effective communication of all subjects of the university environment;

- the integration of information and communication technologies into a single system of a digital university.

Universities are developing their own digital strategies and digital university models. The problems of conceptual imperfection of theoretical models of digital higher education cause challenges in the field of faculty teaching activities. And the paramount problem in this case is the problem of determining the criterion for the teachers' professionalism in modern conditions of digitalization. At the same time, a mandatory permit requires a contradiction between the formation of a mandatory (according to accreditation requirements, the requirements of course retraining and simply the requirements of the time), information and communication competencies of the teaching staff, on the one hand, and insufficient possession of "digital" skills, inability to create content and work in the 
Moodle system, in the university digital environment, to implement e-Learning as a catalyst for innovation in the educational sphere, while ensuring the quality of education.

The experience of Russian universities in supporting the educational process in the context of digitalization is interesting. So, at the Novosibirsk State Technical University, documentary support of the educational process in the information environment of the university is provided by the inspector for work with students. Tutors and administrators of the support service perform communicative, managerial and diagnostic functions in the educational process support system.

In the context of digitalization, the teacher's role is significantly increasing, implementing innovative pedagogical technologies in the university digital information environment. It follows from this that the teacher must have a number of additional competencies:

- technical and technological competence;

- possession of modern information and communication technologies;

- communicative competence;

- organizational competence;

- possession of working skills in an electronic educational environment, software;

- management of the students' flows, training materials, the creation of individual educational trajectories.

Surveys, interviews, testing of teachers, analysis of open classes of the teaching staff allowed us to conclude that not all teachers have the necessary competencies to implement the educational process in a digital educational environment, in the context of digitalization.

In accordance with the needs of our time, the rapid growth in the volume of knowledge requires the introduction of new approaches to the organization of education and the search for innovative forms of transfer and development of knowledge and competencies. The accelerated development of digital technologies stimulates the creation and implementation of innovative forms of education that can quickly and effectively adapt to changes in the external environment. At the same time, the education digitalization is impossible without the immersion of all its subjects in a digital educational environment, including information systems, digital devices, sources, tools and services. At the same time, a digital educational environment is created and developed to ensure the work of educational institutions and to solve problems that arise during the preparation and implementation of the entire educational process. In addition, the education digitalization is an important stage in the transformation process of the modern education system, which requires the management of the university's business functions based on modern information and communication technologies.

In this regard, the adaptability of a person to the rapidly changing labor market acquires particular relevance, which requires the development and implementation of an integrated model for the development of a digital university, which should be based on a lifelong learning model that ensures the rapid and timely (warning) development of various courses in specific areas of training using new teaching methods and technologies, including Online, Open \& Flexible. The complex model includes the following elements (Table 1).

Table 1. Subsystems of a comprehensive digital education model.

\begin{tabular}{|l|l|}
\hline \multicolumn{1}{|c|}{ Sign of education } & \multicolumn{1}{c|}{ Type of education } \\
\hline By degree of institutionalization & $\begin{array}{l}\text { Non-formal } \\
\text { Informal }\end{array}$ \\
\hline $\begin{array}{l}\text { By the way of organizing and implementing } \\
\text { the educational process }\end{array}$ & $\begin{array}{l}\text { Remote } \\
\text { Online } \\
\text { Mixed }\end{array}$ \\
\hline
\end{tabular}


According to the study results of the World Economic Forum, some of the main demanded competencies in 2020 are identified as:

- complex problem solving;

- critical thinking;

- creativity;

- staff management;

- coordination of actions of employees;

- emotional intelligence;

- forming opinions and making decisions;

- service orientation;

- interaction, negotiation;

- cognitive flexibility.

At the same time, digital skills become a guarantee of the full development of the digital economy, which made it expedient and relevant to form a model for the digital university development. An important condition for the digital competencies formation and development is the educational institution's understanding of the need to switch to a digital development model (Table 2).

Table 2. A comprehensive model for the digital university development.

\begin{tabular}{|c|c|}
\hline Model blocks & Block content \\
\hline \multirow{3}{*}{ 1. Digital education } & Formation and development of the e-learning system. \\
\hline & Digitalization of educational activities. \\
\hline & $\begin{array}{l}\text { Development of digital competencies of participants in the } \\
\text { educational process. }\end{array}$ \\
\hline \multirow{7}{*}{ 2. Digital Science } & Digitalization of research activities. \\
\hline & Digitalization of international activity. \\
\hline & $\begin{array}{l}\text { Formation and development of a platform for websites of magazines, } \\
\text { collections, etc. }\end{array}$ \\
\hline & Using the e-conference system. \\
\hline & Creation of a system for analyzing publication activity. \\
\hline & Implementation of RFID technologies in the library. \\
\hline & Integration with world scientific systems. \\
\hline \multirow{4}{*}{ 3. Digital management } & Digitalization of organizational and management activities. \\
\hline & Real-time reporting and analytics. \\
\hline & Electronic document management. \\
\hline & $\begin{array}{l}\text { Implementation of visualized business intelligence systems for } \\
\text { operational adoption of organizational and management decisions. }\end{array}$ \\
\hline \multirow{3}{*}{ 4. Digital Marketing } & Formation of a positive image and leadership at the University. \\
\hline & $\begin{array}{l}\text { Presentation of the University in the educational space of Russia and } \\
\text { the world. }\end{array}$ \\
\hline & Implementation of a student rating system. \\
\hline \multirow{3}{*}{ 5. Digital infrastructure } & Development of the University network. \\
\hline & Modernization and development of communication technologies. \\
\hline & $\begin{array}{l}\text { Implementation of personalized Internet access via wireless managed } \\
\text { networks. }\end{array}$ \\
\hline \multirow[t]{4}{*}{ 6. Digital space } & $\begin{array}{l}\text { Development of high-quality open information and educational space } \\
\text { of the University. }\end{array}$ \\
\hline & Creation of the open educational platform. \\
\hline & Organization of information security of the University. \\
\hline & $\begin{array}{l}\text { Organization of a digital campus with digital offices for educational } \\
\text { recipients and University staff. }\end{array}$ \\
\hline \multirow{2}{*}{$\begin{array}{l}\text { 7. Digital culture of the } \\
\text { university }\end{array}$} & Creation of a digital workplace - both a teacher and a student. \\
\hline & Investing in employee digital skills. \\
\hline
\end{tabular}




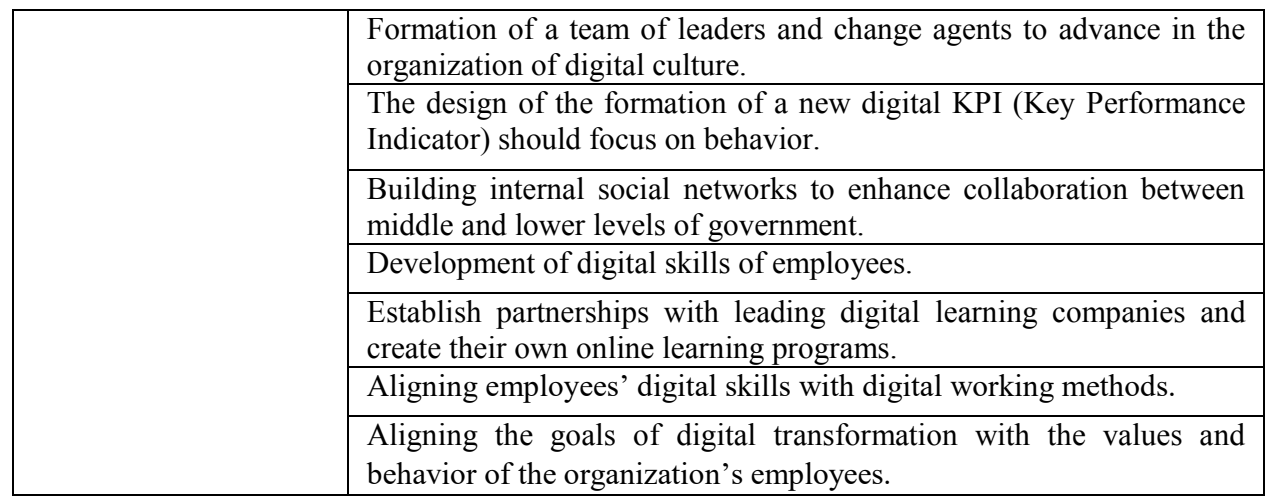

The innovative potential of the digital university allows you to create, perceive and implement innovations, serves as the basis for creating the innovative development model of the digital university, including material and technical resources and human capital.

The material and technical base of the digital university provides for the availability of modern digital technology, programs, premises, etc., ensuring the flexibility of using the material and technical means of education.

Human capital implies the most effective use and, at the same time, the preservation of the professional capabilities of the teaching staff, leaders, administration for the implementation of innovative professional and pedagogical activities in the context of digitalization, as well as the capabilities of students.

A prerequisite for introducing digitalization of education into the educational process is the creation of the university innovative digital environment, which presupposes the presence of the high educational and cultural level of all subjects of the educational process, the possibility of attracting scientific consultants for innovative work, cooperation with higher educational institutions, social partners.

The innovative digital potential of the university in the context of digitalization presupposes:

- interest of participants in innovative activities in a positive end result;

- the competence of the subjects of innovation to implement the innovation;

- the consistency of interests between the subjects of innovation, on the one hand, and with the university administration, on the other.

Digitalization makes high demands on the managerial activities of the head of the educational institution and his personal qualities:

- the manager's awareness of the need to create conditions for the introduction of innovations into the university activities;

- the focus of activities on the formation of an atmosphere of constructive critical attitude of teachers to their work;

- organization of a collective search for solutions to emerging contradictions;

- possession of methods of management, reflection.

It should be noted that a successful digital transformation of education is possible if the University has an appropriate strategy / plan for the development of digital support of the educational process. Each university should pay special attention to the need to establish business ties with industry and business, potential customers of educational services and employers.

This relationship is aimed at:

- acceleration of technology transfer and implementation of the research activities results of the university; 
- joint creation of spin-off and start-up companies, scientific, technical and industrial clusters, technology parks and other innovative structures;

- joint scientific research;

- employment of graduates and training at the request of employers;

- receiving sponsorship from representatives of the business community and business;

- increasing the rating of universities in the educational and scientific services markets;

- strengthening the image and expanding communications of the university with the public.

As for the further prospects for such interaction, efforts should be directed to modeling the economic processes of complex innovative transformations and transformations in the higher education system, as well as to studying the issues of their impact on the development of the higher education system and science on national economic growth. In further works, these aspects will be disclosed.

\section{Conclusions}

Thus, the proposed model for the digital university development should ensure the transition of the University into the state of a digital campus, in which all participants in the educational process will have 24/7/365 access to high-quality information, when all organizational and managerial decisions are fully integrated into educational processes, which implies the possibility for employees and educational recipients not to use the services that are provided in the information and educational environment of the Digital Campus. At the same time, job duties are performed by employees with greater efficiency, and training for higher education recipients is provided of better quality, it becomes transparent, that makes investments in digitalization economically justified.

The center of the University digital development model should be the Digital Campus, which is a modern integral information and telecommunication infrastructure that unites all the electronic systems of the University, provides conditions for the continuous improvement of the education and science quality, makes the University competitive through the use of modern digital technologies.

\section{References}

1. T. Vynnyk, N. Konstantiuk, Significance of educational outcomes for society, Socioeconomic problems and the state, 1(12), 67-73 (2015)

2. N. Gorbunova, R. Timirgaleeva, A. Khrulyova, Managing the development of complex socio-economic systems in the digital economy paradigm, SHS Web of Conf., 87 (2020)

3. G. Johnes, J. Johnes, International handbook on the economics of education, UK, Northampton, MA, USA: Edward Elgar Publishing Ltd. (2004)

4. R.K. Lester, Universities, Innovation, and the Competitiveness of Local Economies, A Summary Report from the Local Innovation Systems Project, MIT IPC Working Paper IPC-05-010 (December 2005)

5. G. Itskowitz, Triple spiral. Universities - enterprises - state. Innovations in action, Tomsk: publishing house state university of control systems and radio electronics (2010)

6. B.R. Clark, Higher education system: academic organization in a cross-national perspective, National Research University "Higher School of Economics" (2011) 
7. B.R. Clark, Creation of entrepreneurial universities: organizational directions of transformation, National Research University "Higher School of Economics" (2011)

8. N. Gorbunova, S. Wang, A.R. Masalimova, J. Bírová, M.G. Sergeeva, Formation of Academic Mobility of Future Foreign Language Teachers by Means of Media Education Technologies, EURASIA Journal of Mathematics Science and Technology Education. Math., Sci Tech, 14(3) (2018)

9. N.V. Gorbunova, A.V. Gluzman, Distance education: realities and prospects, Humanities, 2(50) (2020)

10. N.V. Gorbunova, N.A. Gluzman, University education of the XXI century: vector characteristics of global development trends, Humanities, 4(52) (2020)

11. N.V. Gorbunova, N.A. Gluzman, N.V. Davkush, G.R. Shpitalevskaya, Modernization of teachers' professional training as a strategy for their professionalism formation, Modern problems of science and education, 6 (2020)

12. N.V. Gorbunova, Formation of future teachers' professionalism as a condition of professional success and career development, European Proceedings of Social and Behavioural Sciences ISCKMC (2020)

13. Staying on Top: The challenge of sustaining world-class higher education in the UK, Russell Group Papers, 2 (2010)

14. Prepared by the U.S. Department of Commerce in consultation with the National Economic Council, The Competitiveness and Innovative Capacity of the United States (January 2012) 